\title{
Pregnancy outcome in elderly primigravidae at a Nigerian Tertiary Hospital: a five-year review
}

\author{
R. O. Opadiran, A. D. Isah*, N. Adewole, K. I. Omonua
}

Department of Obstetrics and Gynecology, University of Abuja Teaching Hospital Abuja, Nigeria,

Received: 09 December 2017

Revised: 10 January 2018

Accepted: 12 January 2018

\section{*Correspondence:}

Dr. A. D. Isah,

E-mail: denisanthonyisah@yahoo.com

Copyright: () the author(s), publisher and licensee Medip Academy. This is an open-access article distributed under the terms of the Creative Commons Attribution Non-Commercial License, which permits unrestricted non-commercial use, distribution, and reproduction in any medium, provided the original work is properly cited.

\section{ABSTRACT}

Background: Pregnancy though a physiologic process also comes with its complications. This has been found to be related to factors associated with the mother and fetus. Maternal age at first pregnancy is a determining factor which could affect pregnancy outcome. Objective of present study was to determine the effect of maternal age on obstetric outcome.

Methods: A five-year retrospective case control study involving primigravid women aged 35years and above (elderly primigravidae) and the younger primigravidae aged below 35 years who delivered at the University of Abuja Teaching hospital (UATH) between 2012 and 2016. Data were collected from their case notes, antenatal and delivery registers. For comparative purposes, obstetric and perinatal parameters including antenatal, labour, delivery, postpartum factors were collected for both the elderly primigravidae and younger primigravidae. A total of 6,052 deliveries, of which 2,456 were primigravidae and 42 of them were $\geq 35$ years of age. Out of 42 cases, only 30 folders were found and analyzed. The matched controls were selected consecutively after each elderly primigravidae in the register without prior knowledge of their pregnancy outcome. The data was analyzed using SPSS version 20 . Chi square test $\mathrm{X} 2$ and student $\mathrm{T}$ test were used for comparison of the two groups. Statistical significance was set at $\mathrm{P}$ values of $\leq 0.05$ at $95 \%$ confidence interval.

Results: The incidence of elderly primigravidae was found to be $1.2 \%$ in this study. There was increased risk of hypertensive disorders in pregnancy, caesarean delivery and low APGAR scores in the elderly primigravidae group but these were not statistically significant. No other differences in obstetrics and neonatal outcome were found between the two groups.

Conclusions: Elderly primigravidae are at increased risk of hypertensive disorders in pregnancy and caesarean delivery than in younger primigravidae. On the other hand, neonatal outcome of the two groups were comparable.

Keywords: Elderly primigravidae, Outcome, Pregnancy

\section{INTRODUCTION}

Elderly primigravidae have a high risk of complications including medical conditions in pregnancy, malpresentations, increased incidence of instrumental deliveries and caesarean section rate to mention a few. ${ }^{1}$
The age at first delivery is influenced by various socioeconomic, religious and complex cultural variables which varies from nation to nation. ${ }^{2-4}$ Career advancement and increase in the rate of divorce followed by remarriage have been found to be important contributing factors to this upward trend..$^{5-7}$ Data suggest 
that around $40 \%$ of all women develop some complication. $^{5}$

Elderly primigravidae are generally believed to have decreased fertility and increased risk for adverse pregnancy outcome. ${ }^{8}$

Poor oocyte qualities is associated with an increased risk for aneuploidy, chromosomal abnormalities and spontaneous abortion in this group of women who are routinely screened for these abnormalities in some countries. ${ }^{9}$ However with the improvement in obstetric care this risk have continued to be a subject of controversy. ${ }^{10}$ Some authors noted that pregnancy and birth outcomes in elderly primigravidae are poor, while others reported no difference. ${ }^{7,11-14}$

Therefore, this study was designed to compare pregnancy and birth outcomes of elderly primigravidae with their younger counterparts.

\section{METHODS}

A five year retrospective case control study involving primigravid women aged 35years and above (elderly primigravidae) and the younger primigravidae aged below 35 years who delivered at the University of Abuja Teaching hospital (UATH) between 2012 and 2016.

Data were collected from their case notes, antenatal and delivery registers. For comparative purposes, obstetric and perinatal parameters including antenatal, labour, delivery, postpartum factors were collected for both the elderly primigravidae and younger primigravidae. A total of 6,052 deliveries, of which 2,456 were primigravidae and 42 of them were $\geq 35$ years of age. Out of 42 cases, only 30 folders were found and analyzed.

The matched controls were selected consecutively after each elderly primigravidae in the register without prior knowledge of their pregnancy outcome. The data was analyzed using SPSS version 20.

Chi square test $\mathrm{X} 2$ and student $\mathrm{T}$ test were used for comparison of the two groups. Statistical significance was set at $P$ values of $\leq 0.05$ at $95 \%$ confidence interval.

\section{RESULTS}

A total of 6,052 delivered during the period under review, out of which $40.6 \%$ were primigravidae. Elderly primigravidae constituted $1.2 \% \quad(n=30)$ while younger primigravidae were $98.8 \%(n=2,456)$.

In the study group, $83.3 \%(\mathrm{n}=25)$ had tertiary education compared to $43.3 \%(n=13)$ in the control group while $16.7 \%(n=5)$ had secondary level of education in study group compared to $53.3 \%$ (16) in the control group. The difference was statistically significant $(\mathrm{p}<0.05)$ (Table $1)$.

Parturients in the study group booked early for antenatal clinic compared to their counterparts $(33.3 \%$ versus $13.3 \%$ ) and this was statistically significant.

Table 1: Socio demographic characteristics.

\begin{tabular}{|c|c|c|c|c|c|c|}
\hline & \multicolumn{2}{|c|}{ Study group, $\mathbf{N}=\mathbf{3 0}$} & \multicolumn{4}{|c|}{ Control group, $\mathbf{N}=\mathbf{3 0}$} \\
\hline & Frequency & Percentage & Frequency & Percentage & $\mathbf{X}^{2}$ & P-value \\
\hline \multicolumn{7}{|l|}{ Level of education } \\
\hline Secondary & 5 & 16.7 & 16 & 53.3 & 9.58 & 0.002 \\
\hline Tertiary & 25 & 83.3 & 13 & 43.3 & & \\
\hline Unspecified & 0 & 0 & 1 & 3.3 & & \\
\hline \multicolumn{7}{|c|}{ Gestational age at booking } \\
\hline *Early booking <17 & 10 & 33.3 & 4 & 13.3 & 5.39 & 0.020 \\
\hline$*$ Late booking $\geq 17$ & 7 & 23.3 & 15 & 50.0 & & \\
\hline Unbooked & 13 & 43.3 & 11 & 36.7 & & \\
\hline \multicolumn{7}{|c|}{ Gestational age at delivery } \\
\hline$<37$ weeks & 10 & 33.3 & 8 & 30.0 & 0.87 & 0.351 \\
\hline$\geq 37$ weeks & 20 & 66.7 & 22 & 70.0 & & \\
\hline
\end{tabular}

*WHO 2002

Preterm delivery was commoner in the study group (33.3\%) compared to the control group (20.0\%). However, the incidence of term deliveries was $66.7 \%$ in the elderly primigravidae in contrast to the control group $(70.0 \%)$ but these differences were not statistically significant.
Antenatal complications of elderly primigravidae compared with younger primigravidae, the difference between the study and the control group were in preterm labour and PROM; $0.0 \%, 0.0 \%(n=0)$ in the study group compared to $3.3 \%, 3.3 \%(\mathrm{n}=1)$ in the control group (Table 2). 
Mode of delivery, $60.0 \%(n=18)$ in the study group had Caesarean section compared to $33.3 \%$ (10) in the control group while, $33.3 \%(\mathrm{n}=10)$ had Spontaneous vaginal delivery in the study group and $66.7 \%(n=20)$ in the control group. This was statistically significant with $\mathrm{p}$ $<0.05$ (Table 3).

Table 2: Antenatal complications of elderly primigravidae compared with younger primigravidae.

\begin{tabular}{|lllllll|}
\hline Complication & Study group, & N=30 & Control group N=30 & & \\
\hline Hypertensive disorder in pregnancy & Frequency & Percentage & Frequency & Percentage & $\mathbf{X}^{\mathbf{2}}$ & P-value \\
\hline Diabetes Mellitus & 8 & 26.7 & 3 & 10.0 & 0.12 & 0.732 \\
\hline Uterine fibroid & 1 & 3.3 & 0 & 0.0 & 0.47 & 0.495 \\
\hline APH & 3 & 10.0 & 2 & 6.7 & 0.12 & 0.495 \\
\hline Anaemia in pregnancy & 1 & 3.3 & 0 & 0.0 & 0.47 & 0.778 \\
\hline Malaria in pregnancy & 4 & 13.3 & 2 & 6.7 & 0.02 & 0.891 \\
\hline Preterm labour & 3 & 10.0 & 0 & 0.0 & 1.51 & 0.220 \\
\hline Post term & 0 & 0.0 & 1 & 3.3 & 2.30 & 0.003 \\
\hline Macrosomia & 1 & 3.3 & 3 & 10.0 & 1.07 & 0.301 \\
\hline PROM & 1 & 3.3 & 0 & 0.0 & 0.47 & 0.495 \\
\hline No complication & 0 & 0 & 1 & 3.3 & 2.30 & 0.003 \\
\hline
\end{tabular}

Table 3: Mode of delivery of elderly primigravidae and younger primigravidae.

\begin{tabular}{|llllll|}
\hline & Study group, $\mathbf{N = 3 0}$ & \multicolumn{2}{c|}{ Control group, N=30 } \\
\hline Mode of delivery & Frequency & Percentage & Frequency & Percentage & P value \\
\hline Spontaneous vagina delivery & 10 & 33.3 & 20 & 66.7 & 0.020 \\
\hline Instrumental vagina delivery & 2 & 6.7 & 0 & 0.0 & 33.3 \\
\hline Caesarean section & 18 & 60.0 & 10 & 33 \\
\hline
\end{tabular}

Intrapartum complication, preeclampsia accounted for $10 \%(n=3)$ in study group and $3.3 \%(n=1)$ in control group. However, this was not statistically significant (Table 4). Average gestational age and mean birth weight respectively. The study groups the mean gestational age was 37.2 weeks and mean birth weight was $3.0 \mathrm{~kg}$ compared to 38.5 weeks and $2.8 \mathrm{~kg}$ in the control group. This was not statistically significant (Table 5).

Table 4: Intrapartum complications of elderly primigravidae compared with younger primigravidae.

\begin{tabular}{|c|c|c|c|c|c|c|}
\hline \multirow[b]{2}{*}{ Complication } & \multicolumn{2}{|l|}{ Study group } & \multicolumn{4}{|c|}{ Control group } \\
\hline & Frequency & Percentage & Frequency & Percentage & $\mathbf{X}^{2}$ & P-value \\
\hline Malpresentation & 3 & 10.0 & 3 & 10.0 & 0.00 & 1.000 \\
\hline Fetal distress & 6 & 20.0 & 6 & 20.0 & 0.00 & 0.00 \\
\hline Pre eclampsia & 3 & 10.0 & 1 & 3.3 & 1.07 & 0.301 \\
\hline Cephalopelvic disproportion & 0 & 0.0 & 1 & 3.3 & 0.20 & 0.339 \\
\hline $\mathrm{PPH}$ & 0 & 0.0 & 1 & 3.3 & 1.02 & 0.313 \\
\hline Preterm labour & 0 & 0.0 & 2 & 6.6 & 2.07 & 0.516 \\
\hline Prolonged labour & 1 & 3.3 & 0 & 0.0 & 1.02 & 0.313 \\
\hline Macrosomia & 0 & 0.0 & 1 & 3.3 & 1.02 & 0.313 \\
\hline
\end{tabular}

Table 5: Gestational age and birth weight neonates of elderly primigravidae compared with younger primigravidae.

\begin{tabular}{|c|c|c|c|c|c|c|c|c|}
\hline \multirow[b]{2}{*}{ Parameter } & \multicolumn{2}{|c|}{$\begin{array}{l}\text { Study group, } \\
\mathbf{N}=\mathbf{3 0}\end{array}$} & \multicolumn{2}{|c|}{$\begin{array}{l}\text { Control group, } \\
\mathbf{N}=30\end{array}$} & \multirow[b]{2}{*}{ Mean difference } & \multirow[b]{2}{*}{ 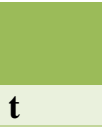 } & \multirow[b]{2}{*}{$95 \% \mathrm{CI}$} & \multirow[b]{2}{*}{ P-value } \\
\hline & Mean & SD & Mean & SD & & & & \\
\hline Gestational age (weeks) & 37.2 & 3.86 & 38.5 & 3.69 & 1.23 & 1.257 & $-0.327-0.749$ & 0.214 \\
\hline Mean birth weight (kg) & 3.0 & 0.72 & 2.8 & 0.82 & 0.19 & 0.966 & $-0.209-0.598$ & 0.338 \\
\hline
\end{tabular}


Table 6: Neonatal outcome of elderly primigravidae compared with younger primigravidae.

\begin{tabular}{|lllllll|}
\hline Parameter & Study group, & $\mathbf{N}=30$ & Control group, $\mathbf{N}=\mathbf{3 0}$ & & \\
\hline Birth Asphyxia & Frequency & Percentage & Frequency & Percentage & $\mathbf{X}^{2}$ & P value \\
\hline Still birth & 9 & 30.0 & 7 & 23.3 & 2.01 & 0.571 \\
\hline Preterm birth & 2 & 6.7 & 1 & 3.3 & & \\
\hline No complication & 10 & 33.3 & 8 & 26.7 & & \\
\hline Apgar Scores & 9 & 30.0 & 14 & 46.7 & & \\
\hline $0-3$ & 1 & & & & & \\
\hline $4-6$ & 8 & 3.3 & 2 & 6.7 & 0.91 & \\
\hline $7-10$ & 19 & 26.7 & 5 & 16.7 & & \\
\hline
\end{tabular}

Birth asthyxia, preterm delivery, still birth and low apgar score at 1 and 5 minutes respectively were more common in the study group compared to the control group (Table $6)$.

\section{DISCUSSION}

The incidence of primigravidae in this study was $40.6 \%$, $1.2 \%$ of them were elderly primigravidae of $\geq 35$ years of Port Harcourt and $1.6 \%$ reported in Jordan. ${ }^{15,16}$ This proportion seems to be lower compared to other studies age. This incidence is higher than those found in Maiduguri $0.42 \%, 0.07 \%$ reported in Ibadan, and $0.65 \%$ reported in Malaysia but lower than $1.4 \%$ reported in, which reported an incidence of $24.5 \%$ of primigravidae above 40 years old. ${ }^{15,17-19}$ This is related to the recent trend in industrialised countries towards delayed child bearing that reflects the increasing commitment of women to prolonged training and professional employment this was also reflected in this study as most of the elderly primigravidae are of tertiary level of education. $^{20}$

The lower incidence found in Northeast Nigeria Bornu state $(0.42 \%)$ is because women of this part of Nigeria venture into marriage at an earlier age and therefore, start child bearing before they are 35 years. ${ }^{15}$ However, the recent National Demorgraphic Health Survery in 2008 showed that the age at first birth is rising slowly and the average age at first birth in the North Eastern Nigeria was 18.2 years. $^{21}$

Similarly, Joseph et al and Oboro and Dare, found an increase in Hypertensive disorders in pregnancy in the older women. ${ }^{22,23}$ This was found in this study, were elderly primigravidae had the highest number of hypertensive disorders in pregnancy than then younger mothers.

Present findings however, was in contrast to the findings by Ojule et al who reported no increase in occurrence of hypertensive disorders in pregnancy among elderly primigravida. ${ }^{18}$
Additionally, caesarean section for elderly primigravidae was higher than the younger primigravidae. This is similar to the series reported from other centers. ${ }^{15,24-26}$ Maternal age as a cause of increased maternal and perinatal morbidity and mortality has made a routine recommendation for caesarean section for these women in the past and this recommendation has been maintained by many Obstetricians. The higher concern for safety among the elderly primigravidae has been reported earlier by Windrigde et al. ${ }^{27}$

Maternal and obstetrician's concern might be responsible for the undue intervention in the elderly primigravidae. Until evidence of the benefit of such intervention is established, elderly primigravidae should have adequate counselling and be allowed to make informed choice on their mode of delivery and also be supported to try vaginal delivery were feasible. ${ }^{15}$

Present study shows that gestational age and mean birth weight were not statistically significant. Contrasting findings were made by other Authors like Jahromi and Husseini, were the mean birth weight was significantly lower in the newborn of eldely primigravidae than younger mothers. ${ }^{28}$

Present study revealed no significant difference in terms of foetal outcome, still birth, birth asphyxia and preterm delivery between the two groups but there was APGAR score in elderly primigravidae compared to younger mothers. This finding is similar to those found by Ojule et al and Oboro and Dare. ${ }^{14,23}$

\section{CONCLUSION}

Elderly primigravidae are at increased risk of hypertensive disorders in pregnancy and caesarean delivery than in younger primigravidae. However, there is no difference in the fetal outcome between the two groups.

Probably there is need for elder primigravide to be given a chance at vaginal delivery. However, multicentre trial 
could be carried out in our environment to determine if there is any difference in fetal outcome.

Funding: No funding sources

Conflict of interest: None declared

Ethical approval: Not required

\section{REFERENCES}

1. Nagarwal K, Chandrakanta, Gaur K, Manohar RK. Pregnancy outcome comparison in elderly and nonelderly primigravida attending at Mahila Chikitsalay, Jaipur (Rajasthan) India. International Multispecialty J Health. 2015;1:24-30.

2. Maxwell NL. Individual and aggregate influences on the age at first birth. Population Res Policy Rev. 1991;10:27-46.

3. Pebley AR, Casterline JB, Trussell J. Age at first birth in 19 countries. Int Plann Perspect. 1982;8:2-7.

4. Gharoro EP, Igbafe AA. Maternal age at first birth and Obstetric Outcome. Nigerian J Clin Pract. 2002;5:20-4.

5. Bayrampour H, Heaman M, Duncan KA, Tough S. Comparison of perfection of pregnancy risk of nulliparous women in advanced maternal age and younger age. J Midwifery Womens Health. 2012;57:445-53.

6. Roa KS. Community health nursing. $4^{\text {th }}$ ed. 2004:449-92.

7. Berkowitz GS, Skoovron ML, Lapinski RH, Berkowitz RL. Delayed Childbearing and the outcome of pregnancy. N Engl J Med. 1990;332:65964.

8. Choe V, Fretts R. Pregnancy and advanced maternal age. In: Studd J, Linta S, Chervena KF editors Progress in Obstetrics and Gynaecology. $17^{\text {th }}$ ed. Philadelphia: Elsevier Publishers; 2006:113-24.

9. Anate M, Akeredolu O. Pregnancy outcome in Elderly primigravidae at the university of Ilorin Teaching hospital, Nigeria. East Afr Med J. 1996;73:543-51.

10. Suwanrath C, Pinjaroens. Pregnancy outcome in elderly primigravida in Songklanagarind Hospital. Songkla Med J. 1998;16:57-63.

11. Ales KL, Drusin ML, Santini DL. Impact of advanced maternal age on the outcome of pregnancy. Surg Gynaecol Obstet. 1990;171 209-16.

12. Breart G. Delayed childbearing. Eur J Obstet Gynaecol Reprod. 1997:71-73.

13. Urguhart DR, Tai C. Obstetric performance in elderly Malaysian primigravida. Asia Oceania J. Obtet Gynaecol 1991;17:321-5.
14. Ojule JD, Ibe VC, Fiebai PO. Pregnancy outcome in elderly primigravidae. Ann Afr Med. 2011;10:2048.

15. Bako B, Unuwa I, Geidam AD, Garba MA. Pregnancy outcome in elderly primigravidae at the University of Maiduguri Teaching hospital, Maiduguri, Nigeria. Int $\mathbf{J}$ Med Medic Sci. 2013;3:476-80.

16. Shehadeh A. Elderly primigravida and pregnancy outcome. JRMS. 2002;9(2):8-11.

17. Sivalingam N, Avalani C. The elderly primigravidaEvaluation of 90 cases. Sing Med J. 1989;30:460-5.

18. Illesanmi AO, Fawole O, Olaleye DO, Arowojolu A. Pregnancy outcome in the elderly primigravidae. J Obstet Gynaecol. 1998;18(1):40-3.

19. Chan BC, Lao TT. Influence of parity on the obstetric performance of mothers aged 40 years and above. Hum Reprod. 1999;14(3):833-7.

20. Buehler JW, Smith JC, Rochat RW. Maternal mortalityin women aged 35years or Older. JAMA. 1986;255:53-7.

21. Fertility levels trends and differentials. In: Nigeria Demographic Health Survey. National Population Commission Federal Republic of Nigeria. Abuja, Nigeria:51-61.

22. Joseph KS, Allen AC, Dodds L, Turner LA, Scott H, Liston R. The perinatal Effects of Delayed Childbearing. Obstet Gynaecol. 2005;105:1410-8.

23. Oboro VO, Dare FO. Pregnancy outcome in nulliparous women aged 35 or older. West Afr J Med. 2006;25(1):65-68.

24. Pandit S, Kale D. Obstetric outcome in elderly primigravida. How did they fare? Bombay Hospital J. 2011;53(4):715-20.

25. Cleary-Goldman J, Malone FD, Vidaver J, Ball RH, Nyberg DA, Comstock $\mathrm{CH}$, et al. Impact of maternal age on Obstetric outcome. Obstet Gynaecol. 2005;105:983-90.

26. Naqvi MM, Naseem A. Obstetrical risks in the older primigravida. J Coll Physicians Surg Pak. 2004;14(5):278-81.

27. Windridge KC, Berryman JC. Women's experience of giving birth after 35. 1999;26:16-23.

28. Jahromi BN, Husseini Z. Pregnancy outcome at maternal age 40 and older. Taiwan $\mathbf{J}$ Obstet Gynaecol. 2008;47(3):318-21.

Cite this article as: Opadiran RO, Isah AD,

Adewole N, Omonua KI. Pregnancy outcome in elderly primigravidae at a Nigerian Tertiary Hospital: a five-year review. Int J Reprod Contracept Obstet Gynecol 2018;7:391-5. 